\title{
Effects of Additive Feeding with Pollen and Water on Some Characteristics of Honeybee Colonies and Pine Honey Production
}

\author{
Halil Yeninar $^{1 *}$, Ethem Akyol ${ }^{2}$, Alaeddin Yörük ${ }^{3}$ \\ ${ }^{1}$ Department of Animal Science, Agricultural Faculty, Kahramanmaraş Sütçü İmam University, 46100 Onikişubat/Kahramanmaraş, Turkey \\ ${ }^{2}$ Animal Production and Technologies Department, Agricultural Sciences and Technologies Faculty, Niğde University, 51240 Niğde, Turkey \\ ${ }^{3}$ Düziçi Vocational High School, Osmaniye Korkut Ata University, 80600 Düziçi/Osmaniye, Turkey
}

A R T I C LE IN F O

Article history:

Received 06 November 2015

Accepted 19 November 2015

Available online, ISSN: 2148-127X

Keywords:

Honeybee

Pine honey

Additive feeding

Honey production

Wintering ability

* Corresponding Author:

E-mail: yeninar@ksu.edu.tr

\section{A B S T R A C T}

This study was carried out to determine the effects of additive feeding with pollen and water on honey yield, colony population, winter loses and wintering ability of colonies in pine honey production season in Muğla province of Turkey. Total twenty honeybee colonies had similar physiological pattern (queen age, genotype, amount of adult worker bees (number of frames covered with adult worker bees), sealed brood areas $\left(\mathrm{cm}^{2}\right)$ and food stocks) were used and randomly divided into four groups. Three of them were fed extra with pollen+water, pollen and water. The control colonies were not given additive foods. Honey yield in pollen+water, pollen, water and control groups were found to be $24.2 \pm 1.1,17.3 \pm 0.8,16.3 \pm 1.0$ and $12.0 \pm 0.6 \mathrm{~kg} /$ colony respectively. Group means were statistically significant. From September 25 to February 15 (wintering), losses of the adult worker bees in pollen+water, pollen, water and control groups were $50 \%, 69 \%, 68 \%$ and $82 \%$, decrease of sealed brood areas in the groups were $48 \%, 66 \%, 68 \%$ and $85 \%$, respectively. Wintering ability of pollen+water, pollen, water and control groups were found to be $92.1 \pm 3.2,70.4 \pm 17.8,67.1 \pm 16.7$ and $51.0 \pm 21.2 \%$ respectively. The results showed that additive feeding in pine honey production season, especially feeding with both pollen+water provided nearly $100 \%$ more honey production and $80 \%$ better wintering ability than the control group. In addition, feeding with only pollen or water had similar positive effect (approximately 40\%) better than control group

\section{Introduction}

Honey bees need to carbohydrates, proteins, fats, minerals, vitamins and water for survival characteristics as growth, development, maintenance and reproduction. The natural foods of the honey bees; consists of pollen, nectar, honeydew or honey and water. When these materials are not available in the field or the hive, supplementary feeding may help the colony survive, or make it more populous so it will produce more honey or be better able to pollinate crops.

Pollen is a honeybee's major source of proteins, fatty substances, minerals, and vitamins (Gary, 1992). Adult bees can survive with carbohydrates and water; however proteins, lipids, minerals, sterols and vitamins are necessary for growth and development of young bees, broods and queens. Pollen is not only essential for the production of brood food, but also for the worker bees to build up their body tissues with in the first days after the emergence (Maurizio 1954; Herbert 1992, Imdorf et al., 1998). Two factors influence the need of pollen: the quantity of pollen stored in cells on combs and the amount of brood (Hellmich et al., 1985; Fewell and Winston, 1992).

Pollen consumption is dependent on the age and the function of the worker bees. Pollen is consumed by nurse bees, which secrete brood foods from their hypopharyngeal glands. Young larvae and queens are fed by nurse worker bees and they obtain their proteins from royal jelly. If nurse bees do not get enough pollen or some other appropriate protein source, their food gland secretions are not adequate for support of normal growth and development of the larvae and egg production of the queens. The amount of fresh pollen required to complete development of a worker bee from larval to adult stage has been estimated approximately 120 to $145 \mathrm{mg}$ of pollen (Alfonsus, 1933; Haydak, 1935).

Proteinaceous jelly is not only produced to nourish the immature members of the colony, but also to be transferred towards other adult worker bees, drones and the queen (Crailsheim, 1991). Therefore, pollen consumption is dependent on the age and the function of the worker bee. In normally developing colonies during summer, nurse-aged bees feed on large amounts of pollen, while other task groups seemingly do not (Crailsheim et al., 1992).

Under favorable foraging conditions; the annual pollen requirement of a honey bee colony varies considerably depending on colony location, strength and floral sources, ranging from 15-55 kg (Armbruster, 1921; 
Haydak, 1935; Todd, 1940; Eckert, 1942). Unlike nectar or honey stores, amount of pollen are fairly small, about one kg at any given time (Jeffree and Allen, 1957; Fewell and Winston, 1992).

If fresh pollen cannot be obtained from the field for about five days or a week; the nurse bees start to eat some of their unsealed larvae in the colony. Older larvae can survive even worse pollen supply situations and shortening of the time until larvae were sealed, but younger larvae than 3 days old are more susceptible 4-5 days old larvae (Seeley and Visscher, 1985).

Water is a vital element for honey bee colony and individual bees in the colony. Honey bees without water will die within a few days. Water serves very important functions which carrying dissolved food materials to all part of body, assisting the removal of waste products, digesting and metabolizing food in honeybee body. Acts of water collection are crucial three parts of a colony's physiology: thermoregulation, humidity of the brood nest and nutritive materials production for the young larvae and queen. Lack of water; nutrition, physiology, brood rearing and behavior of bees are adversely affected. Colony needs to gather water can come from two opposite weather conditions: hot days, when a colony faces a threat of lethally high temperatures inside the hive, and chilly days when a colony faces reduced nectar intake due to diminished foraging. If a colony in a very hot environment such a desert, it has no problem cooling as long as there is a sufficient supply of water. The water carries to colony and spread over the brood combs for evaporative cooling by bees. Approximately 580 calories of heat are lost for each gram of water evaporated.

Honey bees also use water to maintain the proper relative humidity in the brood nest to insure egg hatch and prevent larval desiccation. Doul (1980) found the optimum relative humidity for normal hatching to be between 90 and $95 \%$. There was a significant decline in the number of normal larvae that emerged when eggs were incubated at $100 \%$ and $80 \%$ relative humidity. At $50 \%$ relative humidity only $29 \%$ of the eggs hatched into normal larvae, and no eggs hatched at humidity's below $50 \%$.

Turkey has a great beekeeping potential with number of honey bee colonies, rich flora, several ecotypes adapted to different climatic and ecological conditions.

Marchalina hellenica Gen. (Homoptera, Coccoidea, Margarodidae), is a scale insect living on conifer pine trees ( $P$. halepensis, $P$. brutia, $P$. silvestris, $P$. pinea) and fir trees (Abies cephalonica). It feeds by sucking sap of pine and fir trees and discharges through its anus viscous honey-like substances. Honey bees collect this honeydew and convert it into pine honey. M. hellenica has been observed only in countries around the Mediterranean and Aegean basin, such as Turkey, Greece, Aegean islands, Algeria and South Italy.

M. hellenica has a great importance for Turkish beekeeping sector because $15 \%$ of annual honey production comes from pine honeydew honey. Therefore, Turkey is a leader producer country for pine honeydew honey and exports $95 \%$ of the annual production.
Beekeepers are faced with some serious problems in honeydew production season in the pine forests. Because, shortages of some main feeding sources such as pollen and water are seen in this season. Additionaly, brood production stops and the populations of honeybee colonies are decreased tremendously. As a consequence, the cease of the brood rearing results serious colony loses in winter and weak colonies in spring. Therefore, it is very important to supply pollen and water to the colonies for continuous growth. Before wintering, the colonies must replace their fall population with young bees. After pine honey harvesting, the colonies are carried to pollen including regions for new generation before wintering.

There is no information in the literature about the effect of additive feeding of the colony with pollen and water at pine honey production season on honey yield and some characteristics of colony. Thus, this study was carried out to determine the effects of additive feeding with pollen and water on pine honey production and some colony performance parameters (adult bee population, sealed brood area, survival rate, wintering ability and honey yield).

\section{Material and Methods}

Experiments of the study were carried out in the Mugla province, Yerkesik, Kiran village (600 M altitude from see level) at East Aegean region of Turkey. The Mugla ecotype of Apis mellifera anatoliaca colonies were used in the experiment. Experimental colonies were obtained from local beekeepers then re-queened with sister queens and were housed in standard Langstroth hives and equalized with respect to colony strength, sealed brood area, food stocks and colony weights before the research began. Total 20 colonies were randomly arranged into four groups and each group consisted of 5 colonies. During the experiment; the colonies were fed with only pollen(polen used in this study was prepared in the form of cake $(3 / 4$ pollen $-1 / 4$ honey $(w / w))$, pollen and water, only water and control group colonies were fed with nothing. Colonies in pollen group were fed one $\mathrm{kg}$ pollen, pollen+ water group were fed one $\mathrm{kg}$ pollen and water, and water group were fed with only water as ad libitum. Measurements of sealed brood areas and number of frames with adult bees were taken with 21 days. The size of sealed brood areas were calculated according to Fresnaye and Lensky (1961) and the wintering abilities (population reduction) were calculated by the formula given by Genç (1990). After the honey harvesting, the colonies were transported to East Mediterranean region for wintering. In winter season any measurements were done. After wintering the colonies were checked for all studied parameters.

Colony performance parameters (number of frames with adult worker bees and sealed brood areas) were analyzed by Repeated Measure (GLM), honey yield and wintering ability were performed randomized plot design (ANOVA). Group comparisons among the means were done with Duncan's multiple range test. 


\section{Results and Discussions}

The average honey yield of pollen+water, pollen, water and control groups were found to be $24.2 \pm 1.1$, $17.3 \pm 0.8,16.3 \pm 1.0$ and $12.0 \pm 0.6 \mathrm{~kg} /$ colony respectively. Differences between the group means were significant $(\mathrm{P}<0.01)$. The wintering abilities of pollen+water, pollen, water and control groups were found to be $92.2 \%, 70.4 \%$, $67.1 \%$ and $51.0 \%$ respectively and differences between the group means were also statistically not significant $(\mathrm{P}>0.05)$. Survival rates of the groups were found to be the same with $100 \%$. Honey yields $(\mathrm{kg})$, wintering abilities (\%) and survival rates (\%) of groups were given in Table 1.

The results showed that supplementary feeding of honeybee colonies in pine honey production season, especially feeding with both pollen and water provided nearly $100 \%$ more honey yield and $80 \%$ better wintering ability than the control group. In addition, supplementary feeding with only pollen or only water provided $44 \%$ and $36 \%$ more honey yield, $38 \%$ and $32 \%$ better wintering ability, respectively than the control group.

The average $( \pm$ S.E) numbers of frames with adult worker bees taken with 21 days intervals and after wintering in groups were given in Table 2.

As shown in Table 2., the amount of frames covered with adult worker bees are decreased approximately 50\%, $69 \%, 68 \%$ and $82 \%$, in pollen-water, pollen, water and control groups were respectively in time. These results showed that additive feeding in pine honey production season, especially feeding with both pollen and water provided nearly $64 \%$ less loss adult worker bees throughout the wintering period than the control group. In addition, supplementary feeding with only pollen or only water provided about $36-38 \%$ less loss of adult worker bees than the control group.

The size of sealed brood areas $\left(\mathrm{cm}^{2}\right)$ were given in Table 3.

As shown in Table 3., during the periods from September 25 to November 27, losses of the average size of sealed brood areas in pollen+water, pollen, water and control groups were about 48\%, 66\%, 68\% and 85\%, respectively. These results showed that supplementary feeding in pine honey production season, especially feeding with both pollen and water provided nearly $77 \%$ less decrease of sealed brood areas throughout the wintering period than the control group. In addition, supplementary feeding with only pollen or only water provided about $40-42 \%$ less decreases of sealed brood areas than the control group.

Normally developing colonies during summer, nurse aged bees fed on large amounts of pollen (Crailsheim et al., 1992). Doull (1980) demonstrated the effect of supplemental feeding in a year-long test of commercial pollen supplement. Colonies that receives the supplement produced $38 \%$ more honey per colony. Before wintering the colonies must replace its fall population with young bees and have a large, active brood nest by the time natural pollen is available in winter, late winter or early spring. Farrar (1934) found that spring populations in colonies wintered with no pollen were reduced by 78 percent; populations of those colonies wintered with 600 $\mathrm{cm}^{2}$ in of pollen were reduced by only 6 percent.

Table 1 Honey yields $(\mathrm{kg})$, wintering abilities (\%) and survival rates (\%) (mean \pm S.E).

\begin{tabular}{l|cccc}
\hline Groups & $\mathrm{N}$ & Honey Yield $(\mathrm{kg})$ & Wintering Ability (\%) & Survival Rates (\%) \\
\hline Pollen+Water & 5 & $24.2 \pm 1.1^{\mathrm{a}^{*}}$ & $92.1 \pm 30.2$ & 100 \\
Pollen & 5 & $17.3 \pm 0.8^{\mathrm{b}}$ & $70.4 \pm 17.8$ & 100 \\
Water & 5 & $16.3 \pm 1.0^{\mathrm{b}}$ & $67.1 \pm 16.7$ & 100 \\
Control & 5 & $12.0 \pm 0.6^{\mathrm{c}}$ & $51.0 \pm 21.2$ & 100 \\
General Mean & & $17.4 \pm 1.0$ & $70.1 \pm 8.2$ & 100 \\
\hline
\end{tabular}

*Different letters indicate significant differences among the group means $(\mathrm{P}<0.01)$

Table 2 The amount of adult worker bees in groups from September to February (mean \pm S.E).

\begin{tabular}{l|cccccc}
\hline Groups & 25 Sep. & 15 Oct. & 6 Nov. & 27 Nov. & 15 Feb. & $*$ \\
\hline Pollen+Water & $13.2 \pm 0.37$ & $13.2 \pm 0.37$ & $12.4 \pm 0.40$ & $7.2 \pm 0.37$ & $6.6 \pm 0.24$ & $\mathrm{a}$ \\
Pollen & $13.4 \pm 0.24$ & $13.4 \pm 0.24$ & $12.4 \pm 0.24$ & $5.8 \pm 0.37$ & $4.2 \pm 1.07$ & $\mathrm{a}$ \\
Water & $13.2 \pm 0.37$ & $13.2 \pm 0.37$ & $11.4 \pm 0.24$ & $6.0 \pm 0.32$ & $4.2 \pm 1.07$ & $\mathrm{a}$ \\
Control & $13.4 \pm 0.40$ & $11.8 \pm 0.49$ & $9.8 \pm 0.37$ & $4.4 \pm 0.24$ & $2.4 \pm 1.03$ & $\mathrm{~b}$ \\
\hline
\end{tabular}

*Different letters in column indicate significant differences among the group means $(\mathrm{P}<0.01)$

Table 3 Sealed brood areas $\left(\mathrm{cm}^{2}\right)$ in groups from September to November (mean \pm S.E).

\begin{tabular}{l|ccccc}
\hline Groups & 25 Sep. & 15 Oct. & 6 Nov. & 27 Nov. \\
\hline Pollen+Water & $1666 \pm 60.22$ & $1162 \pm 63.57$ & $996 \pm 45.21$ & $859 \pm 39.95$ & $\mathrm{a}$ \\
Pollen & $1816 \pm 69.85$ & $839 \pm 33.52$ & $715 \pm 34.71$ & $619 \pm 31.09$ & $\mathrm{~b}$ \\
Water & $1681 \pm 108.56$ & $770 \pm 37.28$ & $584 \pm 31.72$ & $544 \pm 39.19$ & $\mathrm{~b}$ \\
Control & $1753 \pm 74.86$ & $483 \pm 45.04$ & $200 \pm 14.40$ & $260 \pm 21.68$ & $\mathrm{c}$ \\
\hline
\end{tabular}

*Different letters in column indicate significant differences among the group means $(\mathrm{P}<0.01)$ 
In general, water consumption of a colony is related to the outside air temperature, relative humidity, strength of colony, amount of reared brood and amount of thick nectar and honey for dilution. Water requirement of a colony are quite extensive when large amounts of brood are reared and raises both on hot days, when overheating threatens, and on cool days, when nectar foraging is hampered. The daily water requirements of honeybee colony have been estimated as approximately 150 grams under average condition in spring. Strong colonies can collect up one kilogram water under hot and dry conditions per a day.

In conclusion, pine honey production, wintering ability and survival rates of honeybee colonies can be increased a significant amount with feeding with pollen and water at pine honey production seasons.

\section{References}

Alfonsus EO. 1933. Zum Pollenverbrauch des Bienenvolkes. Archiv für Bienenkunde., 14: 220-223.

Armbruster L. 1921. Vergleichende Eichungsversuche auf Bienen und Wespen. Archiv für Bienenkunde., 3:219-230.

Anonymous. 2015. FAO. Live Animals Statistic: Http://Faostat3.Fao.Org/Home/E 15/6/2015.

Crailsheim K. 1991. Interadult feeding of jelly in honeybee (Apis mellifera L.) colonies, J. Comp. Physiol. B., 161:55-60.

Crailsheim K, Schneider LHW, Hrassnigg N, Bühlmann G, Brosch U, Gmeinbauer R, Schöffmann B. 1992. Pollen consumption and utilization in worker honeybees (Apis mellifera carnica) dependence on individual age and function, J. Insect Physiol., 38:409-419.

Doull KM. 1980. Relationships between consumption of a pollen supplement, honey production and brood rearing in colonies, of honeybees Apis mellifera L. Apidologie., 11:367-374.
Eckert JE. 1942. The pollen required by a colony of honeybees. J. Econ. Entomol., 35:309-311.

Farrar CL. 1934. Bees must have pollen. Gleanings Bee Cult., 62:276-278.

Fewell JH, Winston ML. 1992. Colony state and regulation of pollen foraging in the honey bee, Apis mellifera L., Behav. Ecol. Sociobiol., 30:387-393.

Fresnaye J, Lensky Y. 1961. Methodes d'Apprecation des surfaces de couvain dans les colonies d'Abeilles. Ann Abeille., 4 (4): 369-376

Gary NE. 1992. The activities and behavior of honeybees. In: J. Graham (ed.) The Hive and the Honey Bee, Dadant \& Sons. Hamilton, Illinois, p. 269-373.

Genc F. 1990. Effects of varroa infestation on wintering ability and feeding, flowering area and weight of queens at emergence on colony performance. Ph.D. Thesis, Agricultural Faculty of Ataturk University, Erzurum.

Haydak MH. 1935. Brood rearing by honeybees confined to pure carbohydrate diet. J. Econ. Entomol., 29: 657-660.

Hellmich LR, Kulincevic MJ, Rothenbuhler CW. 1985. Selection for high and low pollen hoarding honey bees. The Journal of Heredity., 76(3):155-158.

Herbert EW. 1992. Honey bee nutrition. In: J. Graham (ed.) The Hive and the Honey Bee, Dadant \& Sons. Hamilton, Illinois,, p 197-234.

Imdorf A, Rickli M, Kilchenmann V, Bogdanov S, Wille H. 1998. Nitrogen and mineral constituents of honey bee worker brood during pollen shortage. Apidologie., 29:315-325.

Jeffree EP, Allen MD. 1957. The annual cycle of pollen storage by honey bees. J. Econ. Entomol., 50:211-212.

Maurizio A. 1954. Pollenernährung und Lebensvorgänge bei der Honigbiene (Apis mellifica L.), Landwirtsch. Jahrb. Schweiz., 62:15-182.

Seeley TD, Visscher PK. 1985. Survival of honeybees in cold climates: the critical timing of colony growth and reproduction. Ecol. Entomol., 10:81-88.

Todd FE, Bishop RK. 1940. Trapping honeybee gathered pollen and factors affecting yields. J. Econ. Entomol., 33:866-870.. 